\title{
SIKAP ORGANISASI KEMASYARAKATAN ISLAM TERHADAP UNDANG-UNDANG NOMOR 17 TAHUN 2013 TENTANG ORGANISASI KEMASYARAKATAN DAN PERPU NOMOR 2 TAHUN 2017 (Perspektif Studi Kebijakan Dakwah)
}

\author{
Mokhamad Abdul Aziz \\ Pascasarjana Konsentrasi Komunikasi Penyiaran Islam (KPI) Universitas Islam Negeri \\ Walisongo Semarang, Pascasarjana MIESP Universitas Diponegoro Semarang. \\ Email: mokhamadabdulaziz@gmail.com
}

\begin{abstract}
Kebebasan berserikat, berkumpul dan berekspresi merupakan bagian dari hak asasi manusia yang dijamin oleh Undang-Undang Dasar Negara Republik Indonesia Tahun 1945. Kebebasan ini juga mencakup penyebaran ajaran agama sebagai ideologi yang ditransformasikan pada kehidupan nyata. Bagi umat Islam, khususnya da'i tentu memiliki cita-cita besar untuk mewujudkan masyarakat adil sejahtera yang diperintahkan oleh Allah SWT. Ini bisa diperjuangkan, salah satunya melalui organisasi sosial. Selama 72 tahun Indonesia merdeka, beberapa peraturan yang dikeluarkan oleh pemerintah untuk mengatur sistem dan mekanisme organisasi massa telah menimbulkan kontroversi dalam organisasi massa Islam. Pada orde baru, beberapa organisasi diancam tidak diakui dan dibubarkan karena menolak asas tunggal Pancasila. Dinamika berlanjut sampai era reformasi. Ini bisa menjadi renungan bagi para pelaku dakwah, terutama mereka yang mengambil jalan organisasi untuk lebih memperhatikan aspek dasar pembentukan administrasi dengan menghormati negara/pemerintahan, karena nantinya akan sangat berpengaruh terhadap keberlanjutan dakwah di masa depan.
\end{abstract}

Freedom of association, assembly and expression is a part of human rights guaranteed by the 1945 Constitution of the State of the Republic of Indonesia. This freedom also includes the propagation of religious teachings as an ideology for transformation to real life. For Muslims, especially da'i certainly have great ideals for the realization of a prosperous fair society that is directed by Allah SWT. It can be fought, one of which can be through social organization. During the 72 years of independent Indonesia, several regulations issued by the government to regulate the system and mechanisms of mass organizations have added controversy to Islamic mass organizations. In the new order, some organizations threatened to be dissolved and not recognized for rejecting the sole principle of Pancasila. The dynamic continues until the reform era. This can be an afterthought for the da'wah perpetrators, especially those who take the path of the organization to pay more attention to the basic aspects of administrative formation with respect to the state/government, because it will subsequently be very influential on the sustainability of da'wah in the future.

Keywords: Da'wah organization, Islamic mass organization, organization law. 


\section{A. Pendahuluan}

Manusia merupakan makhluk yang tidak bisa menafikan interaksi dengan sesamanya. Karena itu, manusia disebut sebagai makhluk sosial. Dorongan manusia sebagai makhluk sosial itulah yang menyebabkan manusia selalu memiliki hasrat untuk berkumpul dan berserikat. Mereka akan membentuk kerumunan, kelompok bermain, kelompok organisasi, baik dari level yang sederhana sampai kepada level yang serius dan menentukan. Dari bidang profesi seperti guru, doker, buruh, tukang becak, dan lainnya sampai kepada bidang seni dan agama. Mereka akan sampai kapanpun akan memiliki hasrat untuk menghimpun diri, menyamakan persepsi dan tujuan dalam rangka memenuhi kebutuhan dan kebahagiaan antarsesama manusia.

Dalam konteks masyarakat Islam, berkumpul bukan hanya kumpulkumpul yang membentuk kerumunan, tetapi menjadi jamaah yang memiliki visi dunia dan akhirat. Dimensi yang kedua ini menjadi pembenda berkumpulnya umat Islam dengan manusia pada umumnya. Umat Islam diajarkan untuk berbagi kebahagiaan dan kesedihan. Selain dari pada itu, berbagi dalam konteks yang lebih penting juga menjadi esensi ajaran Islam yaitu, saling menasihati dalam kebenaran dan kesabaran. ${ }^{1}$ Persoalan yang akan muncul selanjutnya adalah terkait keberadaan manusia yang juga makhluk individu, dengan egoisme dirinya yang terkadang muncul dalam berinteraksi dengan manusia lainnya.

Tidak hanya itu, karena kebenaran manusia bersifat relatif dan kebenaran absolut hanyalah milik Allah Swt, maka tidak jarang manusia jauh dari idealitas kemanusiaan yang berdampak pada disharmonisasi hubungan dengan sesama. Hal inilah yang menjadi penyebab utama sesama individu terlibat konflik dalam kelompok yang telah mereka bentuk, selain karena ragamnya pemikiran manusia yang menyandang sebagai makhluk yang unik. Karena itu perlu adanya control social yang mengantisipasi akan hal ini.

Kebebasan berserikat, berkumpul, dan mengeluarkan pendapat merupakan bagian dari hak asasi manusia dalam kehidupan berbangsa dan bernegara dalam Negara Kesatuan Republik Indonesia yang dijamin oleh Undang-undang Dasar Negara Republik Indonesia Tahun 1945. Dalam menjalankan hak dan kebebasan berserikat, berkumpul, dan mengeluarkan pendapat, setiap orang wajib menghormati hak asasi dan kebebasan orang lain dalam rangka tertib hukum serta menciptakan keadilan dalam

1 Al-Qur'an Surat al-Ashr ayat 3 (Dan hendaklah mereka saling menasehati dalam kebenaran dan kesabaran) . 
kehidupan bermasyarakat, berbangsa, dan bernegara. Sebagai wadah perjuangan, organisasi kemasyarakatan berpartisipasi dalam pembangunan untuk mewujudkan tujuan nasional dalam wadah Negara Kesatuan Republik Indonesia yang berdasarkan Pancasila.

Dewasa ini, semakin banyak organisasi yang didirikan, baik yang berasaskan nasionalisme-sekuler maupun nasionalisme-religious (kegamaan). Menjamurnya ormas dalam sebuah negera tentu memiliki dampak positif sekaligus negatif. Salah satu wujud dampak negatif yang dianggap mengancam Negara Kesatuan Republik Indonesia (NKRI) adalah adanya ormas-ormas yang menolak atau bertentangan dengan Pancasila. Pemerintah berusaha meluruskan ormas yang berperilaku negatif dengan berbagai upaya. Sementara dampak positif yang ada selalu dikembangkan secara massif.

Sampai dengan bulan Juli 2017, pemerintah mengeluarkan Peraturan Pemerintah Pengganti Undang-undang (Perppu) tentang Ormas untuk mengantisipasi ancaman-ancaman tersebut, sekalipun telah ada undangundang sebelumnya yang mengaturnya. Perubahan Undang-undang tentang ormas inilah bentuk kebijakan negara yang dinamis untuk melindungan hak kebebasan rakyat dalam alam demokrasi. Perubahan peraturan tentang ormas ini tidak serta-merta diterima oleh ormas-ormas di Indonesia, termasuk ormas yang berasas atau bernafaskan Islam. Bagi sebagian besar ormas, organisasi merupakan salah satu jalan dakwah Islam, sehingga Islam dapat lebih merata diterima oleh masyarakat Indonesia.

Berangkat dari kenyataan bahwa tidak semua ormas islam dapat menerima Undang-undang nomor 17 tahun 2013 ini, maka tulisan ini akan menjelaskan respon ormas Islam dalam menyikapi kebijakan yang telah dikeluarkan oleh negara berkenaan dengan organisasi kemasyarakatan di Indonesia tersebut. Paradigma yang digunakan adalah kebijakan dakwah dari perjalanan masing-masing ormas Islam terkemuka di negara ini.

\section{B. Pembahasan}

\section{Pengertian Lembaga Sosial Keagamaan}

Lembaga sosial merupakan terjemahan langsung dari istilah asing social-intitution. Akan tetapi, hingga kini belum adanya sepakat mengenai istilah Indonesia yang dapat mengembangkan isi social-intitution tersebut. Ada yang menggunakan istilah pranata, social-intitution menunjuk pada adanya unsur-unsur yang mengatur perilaku masyarakat. Pranata sosial 
adalah suatu sistam tata kelakuan dan hubungan yang berpusat kepada aktivitas-aktivitas untuk memenuhi kompleks-kompleks kebutuhan khusus dalam kehidupan masyarakat. ${ }^{2}$

Dalam kamus Sosiologi dijelaskan bahwa organisasi sosial adalah perkumpulan sosial yang dibentuk oleh masyarakat, baik yang berbadan hokum maupun yang tidak berbadan hukum, yang berfungsi sebagai sarana partisipasi masyarakat dalam pembangunan bangsa dan negara dan juga sebagai makhluk yangselalu hidup bersama-sama, manusia membentuk organisasi sosial untuk mencapaitujuan-tujuan tertentu yang tidak dapat mereka capai sendiri. ${ }^{3}$

Menurut Robert Maclver dan Charles H. Page, lembaga sosial merupakan tata cara atau prosedur yang telah diciptakan untuk mengatur hubungan antar manusia yang berkelompok dalam suatu kelompok kemasyarakatan yang dinamakan asosiasi. Pendapat lain diungkap oleh Leopold Von Wiese dan Howard Becker, yang melihat lembaga kemasyarakatan sebagai jaringan proses-proses hubungan antar manusia dan antarkelompok manusia yang berfungsi untuk memelihara hubunganhubungan tersebut serta pola-polanya, sesuai dengan kepentingankepentingan manusia dan kelompoknya. ${ }^{4}$

Dari definisi di atas, dapat diketahui bahwa yang terpenting dalam lembaga kemasyarakatan adalah hubungan antar individu. Pe-lebel-an organisasi menjadi ciri khas tertentu organisasi sosial tersebut. Sosial, politik, budaya, agama dan label lain selalu melekat dalam kegiatan sosial kemasyarakatan tersebut. Pada akhirnya, label tersebut akan memberikan arah perjalanan organisasi-organisasi yang ada.

Terkait dengan organisasi keagamaan Islam, hal ini sebenarnya telah diatur keberadannya di dalam al-qur'an. Organisasi sosial keagamaan hakekatnya adalah tempat umat Islam berinteraksi dan mengembangkan ajaran agama, yang biasa disebut dengan dakwah. Hal ini terdapat dalam al-Qur'an, Surat Ali Imran; ayat 104 dan 110:

2 Koentjaraningrat, Pengantar Antropologi, (Jakarta: Penerbit Universitas, 1964), hlm. 113

3 Soerjono Soekanto, Sosiologi Suatu Pengantar, (Jakarta: Rajawali Pers, 2005), hlm. 119.

4 Soerjono Soekanto, Sosiologi Sebagai Suatu Pengantar, (Jakarta. Raja Grafindo Persada, 2006), hlm. 296. 


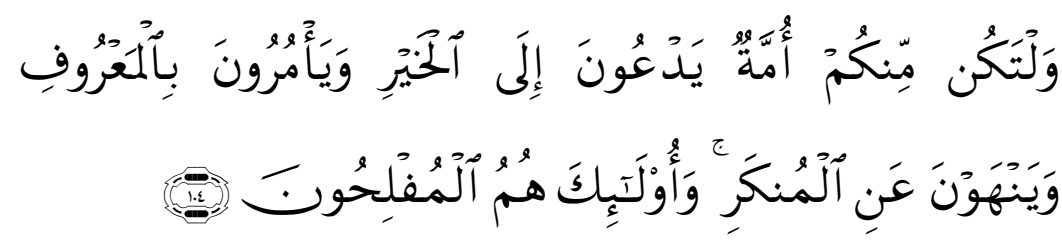

Artinya: "Dan hendaklah ada di antara kamu segolongan umat yang menyeru kepada kebajikan, menyuruh kepada yang ma'ruf dan mencegah dari yang munkar; merekalah orang-orang yang beruntung." (QS. Ali Imran: 104). ${ }^{5}$

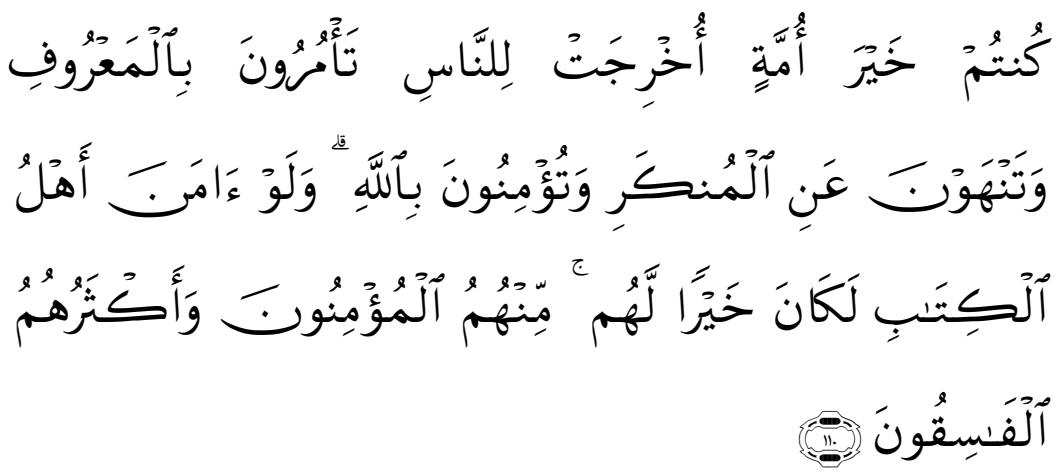

Artinya: "Kamu adalah umat yang terbaik yang dilahirkan untuk manusia, menyuruh kepada yang ma'ruf, dan mencegah dari yang munkar, dan beriman kepada Allah. Sekiranya ahli kitab beriman, tentulah itu lebih baik bagi mereka, di antara mereka ada yang beriman, dan kebanyakan mereka adalah orang-orang yang fasik." (QS. Ali Imran: 110). ${ }^{6}$

Dua ayat di atas dapat dipahami bahwa al-Qur'an memerintahkan kepada manusia, terlebih umat Islam untuk menjadi umat yang terbaik dan umat yang menyeru kepada kebaikan, menyuruh kepada yang ma'ruf dan mencegah dari yang munkar. Inilah yang kemudian mendorong umat Islam untuk mendirikan organisasi sebagai alat perjuangan. Tentu saja sebagai sarana dakwah yang dalam cakupan luas dan masif.

${ }^{5}$ Al-Qur'an, Al-Jamil, (Jakarta: Cipta Bagus Segara, 2012), hlm. 121

${ }^{6}$ Al-Qur'an, Al-Jamil, (Jakarta: Cipta Bagus Segara, 2012), hlm. 122 
Perintah tersebut, tentu memiliki rahasia yang tidak biasa. Beberapa manfaat dari adanya organisasi antara lain: ${ }^{7}$ a) Organisasi sebagai penuntun pencapaian tujuan, b) Organisasi dapat mengubah kehidupan masyarakat, c) Organisasi menawarkan karier baru, d) Organisasi sebagai cagar ilmu pengetahuan, e) Organisasi sebagai ajang merapatkan barisan antar umat Islam. Menguatkan manfaat organisasi, Sahabat Ali Bin Abi Thalib pernah berkata: "al-haqqu bila nizhamin sayaghlibuhu al-bathil bi nizhamin", (kebenaran yang tidak terorganisir akan dikalahkan oleh kebatilan yang terorganisir). ${ }^{8}$ Pernyataan ini menunjukkan begitu pentingnya organisasi untuk mewujudkan suatu tujuan, termasuk dalam menerapkan kebenaran. Persoalannya adalah bagaimana meningkatkan peran maksimal kepada organisasi Islam dalam melaksanakan dakwah?

\section{Lembaga Sosial Keagamaan di Indonesia}

Di Indonesia, lembaga sosial keagamaan atau yang lebih populer disebut Ormas, dengan segala bentuknya, hadir, tumbuh dan berkembang sejalan dengan sejarah perkembangan kehidupan bermasyarakat, berbangsa dan bernegara. Dalam sejarah perjuangan kemerdekaan negara Republik Indonesia, Ormas merupakan wadah utama dalam pergerakan kemerdekaan di antaranya Boedi Oetomo, Sarikat Islam, Muhammadiyah, Nahdlatul Ulama, dan lainnya. Peran dan rekam jejak Ormas yang telah berjuang secara ikhlas dan sukarela tersebut mengandung nilai sejarah dan merupakan aset bangsa yang sangat penting bagi perjalanan bangsa dan negara.

Ada banyak macam lembaga sosial keagamaan di Indonesia, di antaranya yang dianggap mewakili masing-masing agama yang diakui oleh negara, yaitu: Islam: Majelis Ulama Indonesia (MUI), Kristen: Persekutuan Gereja-Gereja Indonesia (PGI), Katolik: Konferensi Wali Gereja Indonesia (KWI), Hindu: Parisada Hindu Dharma Indonesia (PHDI), Buddha: Perwakilan Umat Buddha Indonesia (Walubi), Khonghucu: Majelis Tinggi Agama Khonghucu Indonesia (Matakin). Ormas-ormas ini memiliki peranan penting dalam masyarakat, terlebih hubungannya dengan persoalan agama, juga persoalan lain yang menyangkut agama.

Menurut Dr. Bachtiyar, Kasubdit Ormas Dirjen Kementrian Dalam Negeri (2013), ada sekitar 140 ribu ormas di Indonesia yang terdaftar dan

7 Hasibuan, Malayu S.P., Organisasi dan Motivasi; Dasar Peningkatan Produktivitas, (Jakarta: Bumi Aksara, 2007), hlm. 123.

8 Mohammad Nasih, "Menjawab Panggilan Perbaikan" dalam Mokhamad Abdul Aziz, Membangun Umat dan Bangsa, (Yogyakarta: Bulaksumur Emat, 2016), hlm. Xiii. 
memiliki surat keterangan terdaftar (SKT) dari pemerintah setempat atau Dirjen Dalam Negeri. Sementara yang tidak terdaftar bisa 3 kali lipat jumlahnya. ${ }^{9}$ Banyaknya jumlah ormas ini tentu menjadi "berkah" bagi pemerintah, karena akan ada banyak lembaga yang ikut turut serta membantu pembangunan masyarakat menuju negara-bangsa yang maju dan sejahtera. Namun, hal itu bisa juga berdampak sebaliknya, jika tidak diatur secara detail bagaimana ormas itu dibentuk sampai dengan bisa menjalankan peran dan fungsinya. Oleh sebab itu, diperlukan adanya peraturan khusus yang memuat aturan-aturan terkait dengan organisasi kemasyarakatan.

Mengingat banyaknya jumlah ormas Islam yang ada di Indonesia, maka penulis hanya akan mengungkap respon ormas Islam terbesar dalam merespon Undang-undang Nomor 17 tahun 2013. Berikut ini beberapa ormas Islam yang lahir jauh sebelum kemerdekaan Republik Indonesia 1945:

\section{a. Al-Jami'at Al-Khairiyah}

Organisasi yang lebih dikenal dengan Jami'at Khair ini didirikan di Jakarta pada tanggal 17 Juli 1905. Dan bidang yang di perhatikan oleh organisasi ini ialah (1) pendirian dan pembinaan satu sekolah pada tingkat dasar, dan (2) pengiriman anak-anak muda ke Turki untuk melanjutkan studi. Untuk memenuhi tenaga guru yang berkualitas jam'iat Khair mendatangkan guru dari berbagai daerah bahkan dari luar negri. Pada bulan Oktober 1911 tiga orang guru dari negeri-negeri Arab bergabung ke jami'iat Khair. Mereka Adalah syeh Ahmad Surkati, syeh Muhammad Thaib, syeh Muhammad Abdul Hamid. 10

Ada hal penting yang bisa dicatat adalah bahwa jami'at khair merupakan organisasi pertama/ pelopor yang memulai organisasi dengan bentuk modern dalam masyarakat Indonesia. Jami'at khair dalam perkembangannya melahirkan cikal-bakal organisasi-organisasi baru. Karena jamiat khair digembleng HOS Cokroaminoto dan K.H Ahmad Dahlan. ${ }^{11}$ Terlibatnya Jamiat Khair dalam politik, menyebabkan organisasi ini dicurigai oleh pemerintah

${ }_{9}^{9}$ Pernyataan tersebut disampaikan dalam Sosialisasi UU UU No. 17/2013 tentang Ormas, yang diselenggarakan Badan Kesbangpolinmas Kota Semarang, di hotel Pandanaran Semarang. Lihat http://www.lensaindonesia.com/2013/11/12/tertibkan-ormaspemerintah-sosialisasikan-uu-no-17-tahun-2013.html pada 11 November 2013.

10 Zuhairini, Sejarah Pendidikan Islam, (Jakarta: Direktorat Jendral Pendidikan Kelembagaan Agama Islam, 1986), hlm. 158-159.

11 Hasbullah, Sejarah Pendidikan Islam di Indonesia, (Jakarta : Raja Grafindo Persada, 2001), hlm. 93. 
Belanda. ${ }^{12}$ Selain itu di dalam orang-orang jami'at khair itu sendiri terdapat perdebatan tentang larangan kawin bagi wanita sayyid dengan orang yang bukan keturunan sayyid.

b. Al-Irsyad

Menurut steenbrink dalam Nanun pada Tahun 1913 telah terjadi perpecahan di kalangan jamiat khair, mengenai hak istimewa golongan sayyid. Mereka yang tidak setuju dengan kehormatan berlebihan dari sayyid kemudian mendirikan Jami'ah al-Islam wa al-Irsyad alArabiyah yaitu Syeh Ahmad surkati yang meninggalkan jam'iat Khair dan mendirikan gerakan agama sendiri bernama Al Islah Wal Irsyad, dengan haluan mengadakan pembaharuan dalam reformasi dalam Islam (reformisme).13 Pada tahun 1913 berdirilah perkumpulan AlIslah wal-Irsyad kemudian terkenal dengan sebutan Al-Irsyad. ${ }^{14} \mathrm{Al}-$ Irsyad mendapatkan pengesahan dari Belanda pada tanggal 11 Agustus 1915.

\section{c. Muhammadiyah}

Organisasi Muhammadiyah merupakan organisasi sosial Islam yang berdiri pada tanggal 8 Dzulhijah $1330 \mathrm{H}$, di Yogyakarta atau pada tanggal 18 November 1912 M. Organisasi ini dipelopori oleh K.H Ahmad Dahlan atas saran murid-muridnya dan beberapa orang anggota Budi Utomo untuk mendirikan lembaga pendidikan yang bersifat permanen. ${ }^{15}$ Dari orientasi yang cendrung bersifat keagamaan semacam itu, kita bisa menilai bahwa Muhammadiyah berupaya untuk melakukan pembaharuan kualitatif yang bersifat keagamaan, suatu dialektika internah yang secara inheren memang selalu muncul didalam islam. Dengan semangat kembali kepada Al-Qur'an dan Hadits, Muhammadiyah berupaya keras untuk memurnikan agama dan menghilangkan pengaruh-pengaruh kultural dan simbol-simbol yang tidak relevan dengan islam agar dapat lebih dinamis dalam suasana sosial dan kultural yang baru. ${ }^{16}$

12 Zuhairini, Sejarah Pendidikan Islam, (Jakarta: Direktorat Jendral Pendidikan Kelembagaan Agama Islam, 1986), hlm.161.

13 Hanun, Asrohah, Sejarah pendidikan Islam, (Jakarta: Logos Wacana Ilmu, 1999), hlm. 160 .

14 Zuhairini, Sejarah Pendidikan Islam, (Jakarta: Direktorat Jendral Pendidikan Kelembagaan Agama Islam, 1986), hlm.161-162.

15 Ahmad Syaukani, Perkembangan Pemikiran Modern Di Dunia Islam, (Bandung: CV Pustaka Setia, 2001), hlm. 119-120. hlm. 196.

16 Kuntowijoyo, Pradigma Islam: Interpretasi Untuk Aksi, (Bandung: Mizan, 1991), 


\section{d. Persatuan Islam}

Persatuan Islam atau yang disingkat menjadi Persis, adalah salah satu gerakan pembaharuan yang berdiri di Bandung pada hari Rabu, tanggal 12 September1923 M atau 1 Safar 1342 H., tepatnya di salah satu gang kecil yang bernama Pakgade. Di gang ini banyak berkumpul para saudagar, yang saat itu disebut Urang Pasar. ${ }^{17}$ Awal mula pembicaran pendirian Persis, didasarkan pembicaraan awal antara Yusuf Zamzam, Qomaruddin, dan E. Abdurrahman. Berdirinya Persis juga dimaksudkan membersihkan Islam dari segala bid'ah, khurafat, syirik.

\section{e. Nahdlatul Ulama (NU)}

Nahdlatul Ulama (Kebangkitan Ulama atau Kebangkitan Cendekiawan Islam), disingkat $\mathrm{NU}$, adalah sebuah organisasi Islam besar di Indonesia. Organisasi ini berdiri pada 31 Januari 1926 dan bergerak di bidang pendidikan, sosial, dan ekonomi. Sebab jauh sebelum NU lahir dalam bentuk jam'iyyah (organisasi), ia terlebih dahulu mewujud dalam bentuk jama'ah (community) yang terikat kuat oleh aktivitas sosial keagamaan yang mempunyai karakter tersendiri. ${ }^{18}$ Sejauh ini, NU disebut-sebut sebagai organisasi social keagamaan dengan jumlah anggota terbesar di Indonesia.

Dari lima organisasi sosial keagamaan di atas terlihat bahwa semuanya mempunyai visi-misi dalam mengembangkan Islam sebagai agama, yang notabene adalah dakwah. Dengan platform yang ada ini pada akhirnya masing-masing mensikapi Undang-undang terbaru yang ada dengan harapan melancarkan gerakan dakwah yang dilaksanakannya. Dengan fluktuasi gerakan dakwah pada akhirnya dapat dilihat keberadaan dan tipologi masing-masing ormas tersebut. Hal ini tertunya sangat terkait dengan kondisi politik pemerintahan pada masanya.

Pada zaman reformasi ini, As'ad Said Ali mengklasifikasikan, setidaknya ada lima tipologi ormas yang secara aktual menjadi orientasi politik, yaitu: kiri-radikal, kiri-moderat, kanan-konservatif, kanan-liberal, dan Islamisme. Menurutnya, lima dari tipologi umum itu, empat diantaranya bersumber dari pemikiran Barat (ideologi sekuler, mempunyai spektrum yang sangat luas dari kanan sampai ideologi kiri), dan satu lagi

17 Deliar Noer: Gerakan Moderen Islam di Indonesia, 1900-1942. (Jakarta; LP3ES, 1980), hlm. 95.

18 Ridwan, Paradigma Politik NU - Relasi Sunni-NU dalam Pemikiran Politik (Purwokerto: STAIN Purwokerto Press, 2004), hlm. 169. 
bersumber dari gagasan keagamaan (lebih banyak berasal dari agama Islam). ${ }^{19}$

Islam sebagai agama yang dipeluk mayoritas penduduk Indonesia ketika turut andil menjadi isme dan turut mewarnai dinamika ideologi di era reformasi, tentu menarik perhatian banyak pihak. Masih menurut As'ad Said Ali, Islamisme sebagai ideologi politik di era reformasi dapat dibagi menjadi empat kelompok gagasan, yakni Islam modernis, Islam tradisionalis-konservatif, transformisme Islam, dan Islam fundamental. ${ }^{20}$ As'ad Said Ali membagi organisasi gerakan Islam menjadi dua: mainstream dan non-mainstream. Gerakan Islam mainstream diisi oleh ormas-ormas yang telah dijelaskan di atas, seperti NU, Muhammadiyah, Perti, Persis Al Washliyah.

Secara umum dan tentatif, gerakan baru non-mainstream ini mengambil dua bentuk yaitu: pertama, Non Salafi, yaitu mengikatkan diri dengan semangat mewujudkan doktrin secara kaffah dalam arti literal. Dalam kelompok ini ada beberapa ormas yaitu Darul Arqam, Jamaah Tabligh, Ikhwanul Muslimin, Isa Bugis, IIJABI, FPI, DI, HT dan lain-lain. Kedua, Salafi yang berusaha mewujudkan cita-cita sosial politik Islam yang berbeda dengan formulasi gerakan Islam Mainstream, seperti MMI, Laskar Jihad, Jamaah Islamiyah, Abdul Hakim Haddad, Yazid Jawad, Husein Assewed, kelompok Daurah, Halaqah dan lain-lain. ${ }^{21}$

Dari beberapa kelompok gagasan organisasi Islam diatas, ada macam varian yang menginginkan entitas umat universal di bawah kekhalifahan dunia. Mereka ingin mengubah konsep Negara Kesatuan Republik Indonesia (NKRI) menjadi negara agama, mengganti ideologi negara dari Pancasila menjadi Islam versi mereka, dan bahkan menghilangkan NKRI kemudian menggantinya dengan Khilafah Islamiyah. ${ }^{22}$ Sebenarnya, pada alam demokrasi pemikiran dan gagasan yang demikian itu sah-sah saja. Namun, jika memandang manfaat dan madlarat dengan berbagai spekulasi, perlu adanya filterisasi gagasan untuk menjadi sebuah gerakan yang nyata. Dalam hal ini, negara harus hadir.

19 As'ad Said Ali, Gerakan-gerakan Sosial-Politik dalam Tinjauan Ideologis; Ideologi Gerakan Pasca-Reformasi, (Jakarta: LP3ES, 2012), hlm. x-xi.

${ }^{20}$ As'ad Said Ali, Gerakan-gerakan Sosial-Politik dalam Tinjauan Ideologis; Ideologi Gerakan Pasca-Reformasi, (Jakarta: LP3ES, 2012), hlm. 64.

21 As'ad Said Ali, Gerakan-gerakan Sosial-Politik dalam Tinjauan Ideologis; Ideologi Gerakan Pasca-Reformasi, (Jakarta: LP3ES, 2012), hlm. 68.

22 Abdurrahman Wahid (ed), Ilusi Negara Islam; Ekspansi Gerakan Islam Transnasional di Indonesia, (Jakarta: The Wahid Institute, 2009), hlm. 18 


\section{Respon Ormas Terhadap Kebijakan Publik Tentang Lembaga Sosial Keagamaan}

Undang-Undang Dasar Negara Republik Indonesia Tahun 1945 menjamin kemerdekaan berserikat, berkumpul, dan mengeluarkan pendapat serta memajukan dirinya dalam memperjuangkan haknya secara individu ataupun kolektif untuk membangun masyarakat, bangsa, dan Negara Kesatuan Republik Indonesia sebagai perwujudan hak asasi manusia (HAM). Pasal 28 J ayat (2) Undang - undang Dasar Negara Republik Indonesia Tahun 1945 menyebutkan bahwa dalam menjalankan hak asasi dan kebebasannya secara individu maupun kolektif, setiap orang wajib menghormati hak asasi manusia lainnya dan wajib tunduk kepada pembatasan yang ditetapkan undang-undang dengan maksud semata-mata untuk menjamin pengakuan serta penghormatan atas hak dan kebebasan orang lain dan untuk memenuhi tuntutan yang adil sesuai dengan pertimbangan moral, nilai-nilai agama, keamanan, dan ketertiban umum dalam masyarakat yang demokratis

Berdasarkan kemerdekaan berserikat, berkumpul, dan mengeluarkan pendapat serta memajukan dirinya dalam memperjuangkan haknya di depan negara, terlebih menyangkut agama yang dianutnya, lahirlah lembaga sosial keagamaan atau yang dalam perundang-undangan digunakan term yang lebih umum, yaitu oraganisasi kemasyarakatan atau disingkat Ormas. Ormas atau Organisasi kemasyarakatan adalah sebuah elemen yang selama ini telah ada di dalam masyarakat Indonesia. Bedirinya Ormas ini dimulai ketika sekumpulan masyarakat yang memiliki kesamaan dalam hal tertentu berinisiatif untuk membentuk suatu wadah yang bisa menampung dan menghimpun mereka yang memiliki tujuan yang sama. Berikut ini digambarkan respon masing-masing ormas terhadap peraturan yang terkait dengan Organisasi sosial kemasyarakatan di Indonesia.

\section{UU No. 8 Tahun 1985 dan Peraturan Pemerintah No. 18 Tahun 1986}

Pada Era Orde Baru, tepatnya pada 1985, lahirlah Undang-undang No. 8 Tahun 1985 Tentang Organisasi Kemasyarakatan (Ormas). Undangundang ini berlaku sejak diterbitkan Peraturan Pemerintah Nomor 18 Tahun 1986 pada tanggal 4 April 1986. Peraturan perundangan inilah yang menjadi pedoman bagi ormas-ormas di Indonesia selama kurang lebih 27 tahun sampai akhirnya lahir Undang-undang No. 17 Tahun 2013. Perlu dikethui, pada Masa Orde Baru, Indonesia di bawah kepemimpinan 
Soeharto, pemerintah mulai mencari penyelesaian dari permasalahan yang terjadi pada masa kepemimpinan Soekarno.

Fokus awal yang diambil Soeharto adalah pembenahan di bidang ekonomi. Namun Orde Baru yakin bahwa pembenahan dibidang ekonomi baru akan berhasil jika perpolitikan Indonesia yang menurut Soeharto telah carut marut akibat banyaknya penyimpangan pada masa Orde Lama dapat diselesaikan dengan baik. Karena itu banyak sekali kebijakankebijakan Soeharto dalam bidang politik, salah satunya yaitu pemberlakuan asas tunggal bagi semua organisasi politik maupun organisasi masyarakat baik keagamaan maupun sosial. Gagasan asas tunggal ini menimbulkan pro dan kontra selama tiga tahun sampai diundangkan dalam UU N0.5/1985 dan UU No.8/1985. Pendaftaran kembali ormasormas yang harus sesuai dengan UU NO.8/1985, diberi batas terakhir tanggal 17 juli $1987 . .^{23}$

Hal itu diwujudkan dengan keluarnya UU Nomor 8 Tahun 1985 tentang Organisasi Kemasyarakatan. Pasal 2 ayat (1) UU ini berbunyi "Organisasi Kemasyarakatan berasaskan Pancasila sebagai satu-satunya asas". Dan pasal 2 ayat (2) berbunyi "Asas sebagaimana dimaksud dalam ayat (1) adalah asas dalam kehidupan bermasyarakat, berbangsa, dan bernegara. Ormas yang tidak menerima asas tunggal tidak akan didaftarkan dengan konsekuensi dibubarkan. Secara umum reaksi kalangan Islam mengenai pemberlakuan asas tunggal Pancasila ada tiga macam yaitu: 1) Menerima secara total tanpa kritik; 2) Menerima karena terpaksa sambil menanti keluarnya UU keormasan; dan 3) Menolak sama sekali. Golongan yang pertama adalah PPP, NU, Perti, dan disusul organisasi Islam yang lebih kecil, seperti dewan masjid Indonesia. Golongan yang kedua antara lain Muhamadiyah dan HMI. Sedangkan yang ketiga adalah Pelajar Islam Indonesia (PII) serta tokoh Islam antara lain Deliar Noer, Syafruddin Prawiranegara, Yusuf Abdullah Puar, serta para muballigh yang secara terbuka melalui acara pengajian menyatakan ketidaksetujuannya terhadap asas tunggal. ${ }^{24}$

NU menjadi organisasi masyarakat yang pertama kali menerima pemberlakuan asas tunggal. Keputusan ini diambil pada saat Munas Alim Ulama di Pesantren Salafiyah Safi'iyah, Sukorejo Situbondo pada 18-21 Desember 1983. Persoalan penerimaan asas ini pada mulanya tampak seperti tidak ada persoalan. Sebelum Munas diadakan, Kiai As'ad Syamsul

${ }^{23}$ Abdul Aziz Thaba, Islam dan Negara dalam Politik Orde Baru, (Jakarta: Gema Insani Press, 1999), 265

${ }^{24}$ Abdul Aziz Thaba, Islam dan Negara dalam Politik Orde Baru, (Jakarta: Gema Insani Press, 1999), 265-266. 
Arifin telah menemui presiden Soeharto dan membicarakan tentang pemberlakuan asas tunggal itu. Kiai As'ad mengatakan dan mempertegas bahwasannya NU menerima Pancasila sebagai asas organisasinya bahkan Kiai As'ad menegaskan pendirian para ulama NU dan umat Islam Indonesia bahwa menerima Pancasila adalah hukumnya Wajib. ${ }^{25}$

Sementara organisasi mahasiswa Islam tertua di Indonesia, Himpunan Mahasiswa Islam (HMI) terbelah dalam menyikapi pemberlakuan asas tunggal tersebut. Periode awal penerapan Pancasila sebagai azas HMI (1986 - 1990) merupakan masa konsolidasi internal organisasi HMI sebagai ekses dari terjadinya konflik internal dalam tubuh HMI yang disebabkan atas perbedaan pandangan dan sikap terhadap kebijakan pemerintah orde baru tersebut. Kondisi HMI yang disibukkan dengan urusan domestiknya membuat seluruh konsentrasi dan tenaganya dicurahkan untuk melakukan konsolidasi internal organisasi. Munculnya dualisme HMI pada tahun 1986 merupakan kondisi objektif yang harus dihadapi HMI secara rasional dan proporsional. Sebagai reaksi atas ketidaksepakatan merubah azas HMI, sekitar 8 cabang HMI membuat PB HMI tandingan (HMI MPO, Majelis Penyelamat Organisasi) dan pada proses selanjutnya menjelma menjadi organisasi baru yang berbeda karakteristiknya dengan HMI (DIPO). Namun bagaimanapun juga pada kurun waktu ini kondisi HMI yang sedang rapuh akibat konflik internal ini, membuat responsibilitas HMI pada masalah-masalah kemasyarakatan, kebangsaan, dan kenegaraan terabaikan. ${ }^{26}$

Sedangkan Pelajar Islam Indonesia (PII), yang didirikan pada tanggal 4 mei 1947 di Yogyakarta, menempuh jalan yang berbeda dalam merespon pancasila sebagai asas tunggal. Sebagaimana HMI, PII adalah organisasi independen yang tidak berafiliasi dengan partai politik atau ormas apapun. Namun, PII mempunyai hubungan yang dekat dengan HMI dan dengan organisasi muslim modernis yang lain karena cara pandang keagamaanya, dan mengikuti Islam modernis. Sebagai organisasi bagi pelajar sekolah tingkat atas, PII tetap mempertahankan Islam sebagai asas tunggalnya dan dengan gigih menolak untuk menggantikannya dengan Pancasila. Menurut pandangan PII, Pancasila adalah filsafat negara bukan agama dan jangan sekali-kali dipandang seperti agama. Untuk itu mereka berpendapat bahwa umat Islam harus memiliki sikap yaitu pertama, tidak memandang Pancasila lebih atau di atas proporsi semestinya yaitu memandang Pancasila sebagai agama, apalagi menganggap Pancasila melebihi atau

25 Einar Sitompul, NU dan Pancasila, (Jakarta: Pustaka Sinar Harapan, 1996), hlm. 88.

${ }^{26}$ Agus salim Sitompul, Pemikiran HMI dan Relevansinya dengan Sejarah Perjuangan Bangsa Indonesia, (Jakarta: Integrita Press, 1997), hlm. 122. 
mengatasi agama. Kedua, tidak dapat menggantikan agama (Islam) dengan agama lain atau aliran kepercayaan ataupun ideologi dan filsafat apapun, termasuk Pancasila. ${ }^{27}$

Soeharto menyindir dalam pidatonya bahwa ada partai yang belum mau sepenuhnya menerima Pancasila. Deliar Noer menilai bahwa Soeharto telah salah menempatkan asas Islam sama dengan perkembangan kedudukan agama lain, bahkan Islam dianggap sebagai biang kekacauan dalam putaran kampanye tahun $1982 .{ }^{28}$ Pemaksaan asas tunggal untuk parpol Islam, menurut Deliar Noer telah menafikan kebhinekaan masyarakat yang majemuk yang berkembang menurut keyakinannya masing-masing. ${ }^{29}$ Asas tunggal dipandang Deliar Noer merupakan produk yang menghalang-halangi umat beragama dalam memahami keyakinannya. M. Natsir menegaskan bahwa asas tunggal sebenarnya telah mendeskreditkan Pancasila itu sendiri, artinya asas tunggal pada dasarnya telah menyimpang dari isi dan semangat falsafah Pancasila sebagaimana dihayati oleh perumus Pancasila. ${ }^{30}$ Karena sikapnya ini, Menteri Dalam Negeri melalui keputusannya No.120 dan 121 tanggal 10 Desember 1987 melarang PII dengan alasan, PII tidak mengikuti prinsi-prinsip fundamental UU Keormasan. ${ }^{31}$ Sejauh mengenai ormas Islam, larangan pemerintah ini hanya dikenakan kepada PII. Selainnya, cenderung menerima kebijakan pemerintah tersebut, meskipun sebagian ada yang terpaksa, sehingga memaksa mereka untuk berkonflik dalam internal organiasi mereka.

\section{Undang-Undang Nomor 17 Tahun 2013 Tentang Organisasi Kemasyarakatan}

Tumbangnya rezim orde baru merupakan momentum reformasi politik dan demokrasi. Peristiwa ini terjadi setelah Pemilu 1997. Sehingga periode pelaksanaan pemilu lima tahun berikutnya terpaksa dimajukan digelar tahun 1999. Revisi paket UU bidang politik dilakukan secara radikal. Terbit UU Nomor 2 Tahun 1999 tentang Partai Politik yang antara lain tidak mewajibkan asas tunggal. Pemilu 1999 digelar berdasarkan UU

27 Rusli Karim, HMI-MPO; Dalam Kemelut Modernisasi Politik di Indonesia, (Bandung: Mizan, 1997), 128.

${ }^{28}$ Deliar Noer, Islam, Pancasila dan Asas Tunggal, (Jakarta: Yayasan Perkhidmatan, 1984), hlm. 55.

29 Deliar Noer, Islam, Pancasila ... hlm. 60-61.

30 M. Natsir, Indonesia di Persimpangan Jalan. (Jakarta: Abadi, 1984), hlm. 35.

31 Faisal Ismail, Ideologi Hegemoni dan Otoritas Agama, (Yogyakarta: Tiara Wacana Yogya, 1999), 258. 
Nomor 3 Tahun 1999 tentang Pemilu dengan sistem multi partai. Kontestan pemilu sebanyak 48 parpol. Dari jumlah itu ada 34 parpol berasas Pancasila, 10 parpol berasas Islam, dan 4 parpol berasas lainnya. Tahun 1999 juga terbit UU Nomor 22 Tahun 1999 tentang Pemerintahan Daerah, dan UU Nomor 4 Tahun 1999 tentang Susduk. Juga terbit PP Nomor 5 Tahun 1999 tentang PNS Yang menjadi Anggota Parpol, serta PP Nomor 12 Tahun 1999 tentang Perubahan Atas PP Nomor 5 Tahun 1999. Sampai kepada memasuki tahun 2011, hembusan untuk memperbaruhi UU tentang Ormas menguat. Dalam dinamikanya, Rancangan Undang-Undang tentang Organisasi Kemasyarakatan (Ormas) menuai kontroversi.

Kebijakan publik membahas soal bagaimana isu-isu dan persoalan publik disusun (constructed), didefinisikan, dan bagaimana kesemuanya itu diletakkan dalam agenda kebijakan dan agenda politik. Oleh karena itu, analisis diperlukan untuk mengetahui substansi kebijakan yang mencakup informasi mengenai permasalahan yang ingin diselesaikan dan dampak yang timbul sebagai akibat dari kebijakan yang diimplementasikan. ${ }^{32}$

Sebagaimana dijelaskan di atas, sebelum menjadi UU No. 17 Tahun 2013, RUU Ormas tak dipungkiri menimbulkan kontroversi yang luas di kalangan masyarakat. Hal ini disebabkan oleh adanya interpretasi yang mengatakan bahwa jika RUU Ormas ini disahkan maka negara ini akan kembali menganut rezim otoriterianisme seperti zaman Orde Baru, di mana kebebasan masyarakat sipil untuk berserikat dibatasi dan diancam dengan tidakan represif oleh pemerintah ketika itu. RUU Ormas ini pada dasarnya adalah untuk merevisi UU nomor 8 tahun 1985.

Muhammadiyah yang diwakili oleh Din Syamsuddin dan Abdul Mu'ti mengajukan uji materi banyak pasal dalam UU Ormas ke Mahkamah. Pasalpasal itu antara lain Pasal 1 angka 1, Pasal 4, Pasal 5, Pasal 8, Pasal 9, Pasal 10, Pasal 11, Pasal 21, Pasal 23, Pasal 24, Pasal 25, Pasal 30 ayat (2), Pasal 33 ayat (1) dan ayat (2), Pasal 34 ayat (1), Pasal 35, Pasal 36, serta Pasal 38. Selain itu, Din dan Muhammadiyah juga mengajukan uji materi Pasal 40 ayat (1), ayat (2), ayat (3), ayat (4), ayat (5), dan ayat (6) serta Pasal 59 ayat (1) dan ayat (3). Ketentuan dalam pasal itu, antara lain, mengatur ihwal pendaftaran ormas nonbadan hukum, ketentuan pemilihan kepengurusan ormas, dan adanya campur tangan pemerintah. ${ }^{33}$

32 Lembaga Administrasi Negara Republik Indonesia, Modul Pelatihan Analis Kebijakan, (PDF), hlm. 16-17. Dlakses dari http://www.ksiindonesia.org/files/1447125643\$1\$2XL90\$.pdf pada 21 Mei 2016 pukul 15.05 wib.

33 Koran Tempo, UU Ormas Dikabulkan MK, Muhammadiyah Puas, 26 Desember 2014. 
Pada hari selasa tanggal 23 Desember 2014, Mahkamah Konstitusi (MK) membatalkan beberapa pasal dalam UU Nomor 17 Tahun 2013 tentang Organisasi Kemasyarakatan (UU Ormas). Bahasa MK, pasal-pasal tersebut bertentangan dengan UUD 1945 dan tidak mempunyai kekuatan hukum yang mengikat. Seperti biasa, setelah MK membacakan putusan atas pengujian undang-undang, timbul pelbagai tanggapan. Beberapa diantaranya beranggapan pemerintah tidak dapat lagi sewenang-wenang membubarkan ormas. Atau ada yang berpendapat pemerintah tidak dapat lagi ikut campur urusan ormas.

Pada hari yang sama, MK membacakan dua putusan sekaligus. Putusan MK Nomor 82/PUU-XI/2013 dan Putusan MK Nomor 3/PUUXII/2014. Kedua perkara ini mengajukan obyek hukum yang sama: UU Ormas. Perbedaannya, perkara No. 82/PUU-XI/2013 dimohonkan oleh Pengurus Pusat Persyarikatan Muhammadiyah yang diwakili Din Syamsudin dan Abdul Mu'ti. Sementara perkara perkara No. 3/PUUXII/2014 dimohonkan oleh sejumlah ormas diantaranya Perkumpulan ICW, Yayasan Fitra dan YAPPIKA. Perkara No. 82/PUU-XI/2013 memohon dicabutnya 21 pasal sedangkan perkara No. 3/PUU-XII/2014 memohon dicabutnya 11 pasal. ${ }^{34}$

Kedua permohonan itu ada yang mengajukan pasal-pasal serupa dan ada yang berbeda. Kesimpulannya, dari dua perkara tersebut, MK mengabulkan sebagian permohonan dengan membatalkan 10 pasal dan memberi tafsir konstitusional bersyarat atas 2 pasal. Dari 10 pasal yang dibatalkan MK, ada 3 pasal yang bersifat ultra petitum. Maksudnya MK membatalkan pasal yang tidak dimohonkan (tidak diminta oleh pemohon untuk dibatalkan). Pasal-pasal dalam UU Ormas tersebut adalah: ${ }^{35}$

1) Pasal 8, Pasal 23, Pasal 24 dan Pasal 25

Keempat pasal ini menyangkut tentang ruang lingkup ormas yang terdiri dari nasional, provinsi dan kabupaten/kota. Dengan ruang lingkup yang berbeda tersebut UU Ormas, mensyaratkan adanya struktur organisasi dan kepengurusan. Misalnya Pasal 24 yang mensyaratkan ormas lingkup provinsi harus memiliki struktur dan organisasi dan kepengurusan paling sedikit 25\% dari jumlah

34 Kesbanglinmas Yogyakarta, "Penjelasan Putusan Mahkamah Konstituti Terhadap Undang-undang 17 tahun 2013", Daikses melalui laman: http://www.kesbanglinmas.jogjaprov.go.id/berita/penjelasan-putusan-mahkamahkonstituti-terhadap-undang-undang-17-tahun-2013

35MahkamahKonstitusi, "Putusan Mahkamah Konstitusi", Diakses melalui: http://www.mahkamahkonstitusi.go.id/index.php?page=web.Putusan\&id=1\&kat=1\&cari=8 2\%2FPUU-XI\%2F2013 
kabupaten/kota dalam satu propinsi. Ketentuan adanya ruang lingkup ormas itulah yang dibatalkan oleh MK.

Menurut pertimbangan mahkamah bahwa pembedaan ruang lingkup tersebut dapat mengekang prinsip kebebasan berserikat dan mengeluarkan pendapat yang dijamin konstitusi. Padahal, tidak ada hak dan kebebasan orang lain yang terganggu oleh keberadaan ormas yang memiliki ketiga lingkup tersebut secara bersamaan. Walaupun ormas hanya memiliki kepengurusan pada tingkat kabupaten/kota.

2) Pasal 16 ayat (3), Pasal 17 dan Pasal 18

Ketiga pasal inilah yang disebut di atas sebagai ultra petitum. Sebagaimana pertimbangan mahkamah "Walaupun pemohon tidak menguji Pasal 16 ayat (3), Pasal 17, Pasal 18, tetapi ketiga pasal yang mengatur pendaftaran ormas terkait ruang lingkup Ormas, maka harus dinyatakan inkonstitusioal pula". Ketiga pasal tersebut masuk dalam Bab Pendaftaran (Ormas). Khususnya pejabat yang berwenang yang menerbitkan surat keterangan terdaftar bagi ormas yang tidak berbadan hukum: Menteri untuk ormas ruang lingkup nasional; gubernur untuk ormas provinsi dan bupati/ walikota untuk ormas kabupaten/kota. Ketiga pejabat yang disebut tersebut juga berwenang melakukan verifikasi dokumen pendaftaran, Dan ada penyebutan Camat yang melakukan pendataan ormas tidak berbadan hukum. Dengan dicabutnya ketiga pasal tersebut, maka ormas yang tidak berbadan hukum dapat mendaftarkan diri dimana saja dengan memenuhi persyaratan sebagaimana Pasal 16 ayat (2).

Prinsipnya, ormas yang tidak berbadan hukum dapat mendaftarkan diri kepada semua tingkat instansi pemerintah yang bertanggung jawab dan dapat pula tidak mendaftarkan diri. Ketika ormas yang tidak berbadan hukum telah mendaftarkan diri haruslah diakui keberadaannya dalam lingkup daerah maupun nasional. Sebaliknya jika tidak mendaftarkan diri, negara tidak dapat menetapkan ormas tersebut sebagai ormas terlarang sepanjang tidak melakukan perbuatan melanggar hukum yang tercantum dalam Pasal 59 UU Ormas.

Pasal 34 ayat (1) yang berbunyi "Setiap anggota Ormas memiliki hak dan kewajiban yang sama". Mahkamah memandang bahwa hak dan kewajiban anggota suatu ormas adalah masalah internal (otonom) masyarakat sesuai karakteristiknya. Negara tidak dapat mencampuri dan memaksakan suatu ormas mewajibkan anggotanya memiliki hak dan kewajiban yang sama. Pengaturan demikian bentuk pembatasan yang melanggar prinsip kebebasan berserikat yang dijamin UUD 1945. 
Pasal 40 ayat (1) menyatakan "Pemerintah dan/atau Pemerintah Daerah melakukan pemberdayaan Ormas untuk meningkatkan kinerja dan menjaga keberlangsungan hidup Ormas.". Mahkamah berpendapat negara tidak boleh terlalu jauh mencampuri hak dan kebebasan ormas. Walaupun tujuan pengaturan tersebut baik dan positif bagi pengembangan ormas, tetapi pemberian peran tersebut bertentangan dengan hakikat ormas sebagai organisasi masyarakat yang mandiri dan otonom. "Campur tangan negara dalam pemberdayaan ormas akan mengancam kreativitas masyarakat dalam mengekspresikan hak kebebasan berkumpul dan berserikat yang dijamin oleh UUD 1945,".

Terakhir Pasal 59 ayat (1) huruf a yang berbunyi "Ormas dilarang menggunakan bendera atau lambang yang sama dengan bendera atau lambang negara Republik Indonesia menjadi bendera atau lambang Ormas". Ketentuan ini sebenarnya telah diputuskan oleh MK dalam putusan MK No. 4/PUU-X/2012 tertanggal 15 Januari 2013. Putusan MK itu mencabut larangan penggunaan lambang negara. Artinya, penggunaan lambang negara dibebaskan bagi siapapun atau organisasi apapun. Oleh karena ketentuan Pasal 59 ayat (1) huruf a UU Ormas mengandung muatan materi yang sama dengan pertimbangan hukum dalam putusan MK No. 4/PUU-X/2012, maka putusan MK No. 4/PUU-X/2012 tersebut mutatis mutandis menjadi pertimbangan hukum dalam permohonan a quo.

Sedangkan dua pasal lainnya, MK memberi tafsir konstitusional bersyarat, yakni Pasal 5 dan Pasal 29 ayat (1). Pasal 5 berisi tentang tujuan Ormas. Agar tujuan Pasal 5 tersebut tidak melanggar hak kebebasan berserikat, maka kata "dan" yang terdapat pada Pasal 5 huruf g UU Ormas ditambah dengan kata "/atau" agar tujuan tersebut dapat bersifat alternatif. Sedangkan Pasal 29 ayat (1) dinyatakan inkonstitusional bersyarat sepanjang tidak dimaknai adanya kemungkinan pengambilan keputusan berdasarkan suara terbanyak. Pasal 29 ayat (1) UU Ormas selengkapnya menjadi "Kepengurusan ormas di setiap tingkatan dipilih secara musyawarah dan mufakat (atau dengan suara terbanyak)".

Selebihnya pasal-pasal yang dimohonkan dalam dua perkara di atas, ditolak oleh MK. Satu diantaranya pasal yang dimohonkan untuk dibatalkan adalah Pasal 59 ayat (2) huruf b yang berbunyi "Ormas dilarang melakukan penyalahgunaan, penistaan, atau penodaan terhadap agama yang dianut di Indonesia". Menurut pertimbangan MK, ketentuan larangan itu tidak bertentangan dengan Pasal 28J ayat (2) UUD 1945. Sehingga Pasal yang dimohonkan tersebut ditolak oleh MK.

Direktur Eksekutif Imparsial, Poengky Indarti, menilai UU Ormas yang baru diterbitkan tak bedanya seperti UU Ormas sebelumnya yang 
diterbitkan pada masa pemerintahan Orde Baru. Sebab kedua regulasi itu dinilai punya tujuan yang sama yaitu pengendalian oleh pemerintah terhadap organisasi masyarakat sipil. ${ }^{36}$ Dengan demikian masing-masing lembaga organisasi keagamaan islam telah mempunyai berbagai pandangan tentang Undang-undang ini, sehingga berimplikasi pada gerakan dakwah yang dilaksanakan. Dakwah dijalankan dengan tidak bertentangan pada undang-undang ormas yang ada, yang notabebe juga sebagai lembaga dakwah.

\section{Perppu Nomor 2 Tahun 2017}

Belum selesai dinamika ormas menyikapi UU No. 17 Tahun 2013 Tentang Ormas, Pemerintah menerbitkan Peraturan Pemerintah Pengganti Undang-undang (Perppu) Nomor 2 Tahun 2017 tentang Perubahan atas Undang-Undang Nomor 17 Tahun 2013 tentang Organisasi Masyarakat. Menurut Menteri Koordinator Bidang Politik, Hukum dan Keamanan Wiranto, pemerintah memiliki dasar yang kuat untuk menerbitkan Perppu Nomor 2 Tahun 2017, yaitu aturan undang-undang yang tidak lagi memadai.

Wiranto menjelaskan tiga pertimbangan pemerintah dalam penerbitan Perppu. Pertama, tindakan pemerintah sudah sesuai dengan putusan Mahkamah Konstitusi Nomor 138/PUU-VII/2009. Kedua, terkait aturan hukum yang belum memadai. Perppu bisa diterbitkan untuk memberikan solusi agar tidak terjadi kekosongan hukum. Ketiga, Perppu bisa diterbitkan jika kekosongan hukum tersebut tidak bisa diatasi dengan cara membuat undang-undang baru. Mekanisme dan prosedur untuk membuat undang-undang baru memang membutuhkan jangka waktu yang panjang, dan itu jadi kendala. ${ }^{37}$ Namun demikian, penerbitan Perppu Ormas tersebut mendapat rekasi beragram dari ormas-ormas Islam. Perppu yang ditandatangani Presiden Joko Widodo pada 10 Juli 2017 memuat perubahan signifikan atas Undang-Undang Ormas.

Secara hukum, penerbitan Perppu ini tak salah karena diatur dalam Pasal 22 ayat (1) Undang-Undang Dasar 1945. Namun, dari segi obyektivitas dan substansi, banyak persoalan yang menyebabkan beberapa

36 Hukum Online.Com, UU Ormas Mulai Memakan Korban, 13 Maret 2014. Dikases dari http://www.hukumonline.com/berita/baca/lt5321da472379e/uu-ormas-mulaimemakan-korban pada 22 Mei 2016 pukul 22.30.

37 Kompas, "Ini Tiga Pertimbangan Pemerintah Menerbitkan Perppu Ormas" dalam http://nasional.kompas.com/read/2017/07/12/12232051/ini-tiga-pertimbanganpemerintah-menerbitkan-perppu-ormas pada 12 Juli 2017. 
ormas berbeda dalam menyikapnya. Berikut sikap beberapa ormas Islam terkait terbitnya Perppu tersebut. Pengurus Besar Nahdlatul Ulama (PBNU) mendukung terbitnya Perppu Ormas, karena bisa akan mempercepat proses hukum penanganan ormas radikal, tanpa memberangus hak-hak konstitusionalnya. Ketua Pengurus Harian Tanfidziyah PBNU Robikin Emhas menyatakan bahwa radikalisme, kalau dibiarkan dan hukum serta UU tidak memadai untuk menanggulanginya, maka akan sangat membahayakan persatuan dan kesatuan bangsa. ${ }^{38}$ Selain itu, Ketua Pengurus Besar Nahdlatul Ulama (PBNU) KH Marsudi Syuhud menilai, Perppu No 2 tentang Ormas adalah upaya pemerintah Indonesia untuk menciptakan kemaslahatan bersama dan mencegah kerusakan-kerusakan atas kesepakatan untuk hidup bersama di bawah bendera NKRI sebagaimana telah menjadi konsensus bersama. Menerbitkan perppu itu (Perppu Ormas) antara lain sesungguhnya adalah menjalankan kaidah dar'u al-mafaasid muqoddamun alaa jalbi al-mashaalih (mencegah kemudaratan lebih prioritas dibanding menarik kemanfaatan). ${ }^{39}$

Sedangkan, Pimpinan Pusat Muhammadiyah, Setelah melalui sidang pleno, akhirnya menyatakan sikap resminya terkait Perppu Nomor 2 Tahun 2017 tentang Organisasi Masyarakat atau PERPPU Ormas. Sikap Muhammadiyah ini tertuang dalam Pernyatan Sikap Pimpinan Pusat Muhammadiyah Nomor 364/PER.I.O/A/2017. Pernyataan bertanggal 2 Agustus 2017 itu mempertegas komitmen Muhammadiyah untuk mendukung Negara Pancasila, dan menolak pemutlakan gagasan Khilafah Islamiyah. Muhammadiyah menolak paham yang memutlakkan sistem kekhalifahan Islam yang disertai sikap menegasikan pilihan politik Islam lainnya dengan menuding sebagai sistem di luar Islam (tidak lslami, sistem thaghut), lebih-lebih apabila disertai gerakan untuk mengganti sistem politik yang telah berlaku pada setiap negara Islam atau negara Muslim.

Pimpinan Pusat Muhammadiyah menegaskan, bahwa Negara Pancasila tersebut selain disebut sebagai hasil konsensus nasional (Daar alahdi) dan tempat pembuktian atau kesaksian (Daar al-Syahadah), dapat diposisikan dan difungsikan sebagai negeri yang aman dan damai atau Darussalam (Dar al-Salam). Sebagai hasil konsensus nasional maka

38 Tempo.co, "Perppu Ormas: Reaksi dari MUI, PBNU, hingga Fadli Zon" dalam https://nasional.tempo.co/read/news/2017/07/13/078891054/perppu-ormas-reaksidari-mui-pbnu-hingga-fadli-zon pada 13 Juli 2017.

39 NU.OR.ID, "Perppu Ormas Mencegah Kerusakan" dalam https://www.nu.or.id/post/read/79690/perppu-ormas-untuk-mencegah-kerusakan pada 20 Juli 2017. 
Negara Pancasila mengikat bagi seluruh institusi negara dan komponen bangsa. Oleh karena itu, Muhammadiyah menolak segala paham, eksistensi organisasi, dan gerakan anti Pancasila lainnya yang berusaha mengganti Dasar Negara Pancasila dan Negara Kesatuan Republik Indonesia.

Muhammadiyah bukan hanya menolak gerakan anti-pancasila yang berbasis paham agama. Namun juga mempertegas penolakannya atas paham dan gerakan Komunisme, maupun paham yang ingin menjadikan atau membawa Indonesia menjadi negara sekuler. Muhammadiyah juga menolak segala bentuk separatisme yang ingin memisahkan diri dari Negara Kesatuan Republik Indonesia, maupun segala paham dan gerakan yang meruntuhkan sendi-sendi dasar NKRI. ${ }^{40}$

Wakil Ketua Umum Majelis Ulama Indonesia (MUI) Zainut Tauhid Saadi mengatakan, Perppu Ormas jangan terbit karena menyasar satu ormas saja. Akan tetapi semua ormas yang bertentangan dengan Pancasila dan membahayakan eksistensi NKRI. Menangani ormas bermasalah, kata Zainut, tidak cukup dengan membubarkan ormas melalui pendekatan hukum dan keamanan saja. Lebih penting adalah pengawasan, pendampingan dan pembinaan ormas tersebut agar tidak menyimpang. ${ }^{41}$

Sedangkan beberapa ormas Islam merasa keberatan dan bahkan menolak adanya Perppu tersebut. Salah satu akan mengajukan judicial review adalah HTI, ormas yang menjadi objek nyata Perppu pembubaran ormas. Yusril berargumen Perppu Nomor 2 Tahun 2017 tentang perubahan UU Nomor 17 tahun 2013 tentang Organisasi Kemasyarakatan tidak berdasar. Pasalnya, tidak ada kegentingan yang memaksa dikeluarkannya aturan pengganti. Yusril menilai perubahan regulasi tentang ormas ini bukan hanya menyoal HTI saja, melainkan bakal berdampak luas pada ormas-ormas lain.42 Selain HTI, Front Pembela Islam atau biasa disebut FPI juga akan mengajukan uji materi terhadap Peraturan Pemerintah Pengganti Undang-undang (Perppu) tentang Organisasi Kemasyarakatan

40 Pernyataan Sikap Pimpinan Pusat Muhammadiyah No. 264/PER/I.0/A/2017 Tentang Pro Kontra Perppu Nomor 2 tahun 2017 dan Masalah Keberadaan Negara Pancasila" dalam http://www.aisyiyah.or.id/files/1/file/Pernyataan-Perpu-no-22017_compressed.pdf pada 9 Agustus 2017.

41 Republika, "MUI: Perppu Tidak Hanya Menyasar Salah Satu Ormas Saja" dalam http://www.republika.co.id/berita/nasional/hukum/17/07/13/oszp3x382-mui-perppuseharusnya-tak-sasar-salah-satu-ormas pada 13 Juli 2017.

42 BBC, "Gugat Perppu, Hizbut Tahrir Indonesia Akan Ajukan Uji Materi ke MK" dalam http://www.bbc.com/indonesia/indonesia-40577915 pada 12 Juli 2017. 
ke Mahkamah Konstitusi. ${ }^{43}$ Lebih dari 10 perwakilan ormas menyampaikan penolakan Perppu Nomor 2 tahun 2017 tentang Organisasi Masyarakat yang diterbitkan pemerintah.

Adapun beberapa ormas lain yang juga menolak Perppu Ormas antara lain Persatuan Islam (Persis), Matlaul Anwar, Dewan Dakwah Islamiyah, Syarikat Islam Indonesia, Wahfah Islamiyah, Ikatan Dai Indonesia, Majelis Mujahidin, Korp Mubaligh Jakarta, STH Bogor, BKSPPI Bogor. ${ }^{44}$ Penolakan mereka disebabkan banyak hal yang menyangkut persoalan gerakan yang terbatasi. Hal ini mungkin yang kemudian menyebabkan persoalan baru terhadap gerakan dakwah yang dilakukannya.

\section{Kesimpulan dan Penutup}

Kebebasan berserikat, berkumpul, dan mengeluarkan pendapat merupakan bagian dari hak asasi manusia dalam kehidupan berbangsa dan bernegara dalam Negara Kesatuan Republik Indonesia yang dijamin oleh Undang-Undang Dasar Negara Republik Indonesia Tahun 1945. Hal ini yang menjamin berdirinya organisasi sosial-keagamaan dan kemasyarakatan. Ketentuan peraturan yang mengatur tentang ormas mengalami perubahan dan dengan perubahan yang ada memberikan konsekuensi masing-masing ormas untuk mensikapinya.

Kebijakan ormas dalam mensikapi Undang-undang No 17 tahun 2013 dan Perppu No 2 tahun 2017 beragam. Ada yang menerima dan menolak beberapa pasal yang ada di dalamnya. Dinamika yang terjadi di lapangan menunjukkan bahwa beberapa ormas Islam merasa terancam dan berusaha untuk menolak melalui jalur konstitusi. Namun, pada posisi yang sama terdapat beberapa ormas yang justru mengamini dan mendukung peraturan perundang-undangan yang dikeluarkan pemerintah tersebut. Dinamika ini bisa menjadi pelajaran untuk umat Islam agar lebih berhati-hati menyikapi aturan yang berkaitan dengan ormas sekaligus menjadi bahan renungan ketika akan mendirikan sebuah organisasi kemasyarakat yang tujuannya digunakan untuk berdakwah. Kebijakan

43 CNN, "FPI akan Ajukan Uji Materi Perppu Pembubaran Ormas" dalam https://www.cnnindonesia.com/nasional/20170713144041-12-227638/fpi-akan-ajukanuji-materi-perppu-pembubaran-ormas/ pada 13 juli 2017.

${ }^{44}$ Kompas, "Fadli Zon Terima Forum Ormas Islam, Minta DPR Tolak Perppu Ormas" dalam http://nasional.kompas.com/read/2017/07/18/16220331/fadli-zon-terima-forumormas-islam-minta-dpr-tolak-perppu-ormas pada 18 Juli 2017. 
dakwah ormas pada akhirnya berkembang seiring dengan penyesuaian terhadap peraturan perundangan tersebut.

Kebijakan dakwah yang dikembangkan oleh masing-masing ormas disesuaikan dengan platform yang dimilikinya. Memang belaum banyak yang dapat dijabarkan terkait dengan kebijakan dakwah di artikel ini. Hal penting yang perlu diungkap adalah bahwa kebijakan dakwah yang ada selalu berkembang dan mengedepankan visi-misi organisasi dengan tidak melupakan azas Pancasila dan Undang-undang Dasar Negara RI Tahun 1945. 


\section{DAFTAR PUSTAKA}

Al-Qur'an, Al-Jamil, (Jakarta: Cipta Bagus Segara, 2012).

Ali, As'ad Said, Gerakan-gerakan Sosial-Politik dalam Tinjauan Ideologis; Ideologi Gerakan Pasca-Reformasi, (Jakarta: LP3ES, 2012).

Asrohah, Hanun, Sejarah pendidikan Islam, (Jakarta: Logos Wacana Ilmu, 1999).

Hasbullah, Sejarah Pendidikan Islam di Indonesia, (Jakarta: Raja Grafindo Persada, 2001).

Ismail, Faisal, Ideologi Hegemoni dan Otoritas Agama, (Yogyakarta: Tiara Wacana Yogya, 1999).

Karim, Rusli, HMI-MPO; Dalam Kemelut Modernisasi Politik di Indonesia, (Bandung: Mizan, 1997).

Koentjaraningrat, Pengantar Antropologi, (Jakarta: Penerbit Universitas, 1964).

Kuntowijoyo, Pradigma Islam: Interpretasi Untuk Aksi, (Bandung: Mizan, 1991).

Malayu, Hasibuan, Organisasi dan Motivasi; Dasar Peningkatan Produktivitas, (Jakarta: Bumi Aksara, 2007).

Mubarok, Biky Uthbek, "Problematika Undang-Undang Nomor 17 Tahun 2013 Tentang Organisasi Kemasyarakatan (Studi Kasus Di Kabupaten Sleman)", (Yogyakarta: UIN Sunan Kalijaga, 2015).

Mursiatama, Tirta Nugraha, Laporan Pengkajian Hukum Tentang Peran dan Tanggung Jawab Organisasi Kemasyarakatan dalam Pemberdayaan Masyarakat, (Jakarta: Badan Pembinaan Hukum Nasional Kemenkumham RI, 2011).

Nasih, Mohammad, "Menjawab Panggilan Perbaikan" dalam Mokhamad Abdul Aziz, Membangun Umat dan Bangsa, (Yogyakarta: Bulaksumur Emat, 2016).

Natsir, M. Indonesia di Persimpangan Jalan. (Jakarta: Abadi, 1984).

Noer, Deliar, Islam, Pancasila dan Asas Tunggal, (Jakarta: Yayasan Perkhidmatan, 1984).

Noer, Deliar, Gerakan Moderen Islam di Indonesia, 1900-1942. (Jakarta; LP3ES, 1980). 
Ridwan, Paradigma Politik NU - Relasi Sunni-NU dalam Pemikiran Politik (Purwokerto: STAIN Purwokerto Press, 2004).

Sitompul, Agussalim, Pemikiran HMI dan Relevansinya dengan Sejarah Perjuangan Bangsa Indonesia, (Jakarta: Integrita Press, 1997).

Sitompul, Einar, NU dan Pancasila, (Jakarta: Pustaka Sinar Harapan, 1996).

Soekanto, Soerjono, Sosiologi Sebagai Suatu Pengantar, (Jakarta. Raja Grafindo Persada, 2006)

Soekanto, Soerjono, Sosiologi Suatu Pengantar, (Jakarta: Rajawali Pers, 2005).

Syaukani, Ahmad, Perkembangan Pemikiran Modern Di Dunia Islam, (Bandung: CV Pustaka Setia, 2001).

Thaba, Abdul Aziz, Islam dan Negara dalam Politik Orde Baru, (Jakarta: Gema Insani Press, 1999).

Wahid, Abdurrahman (ed), Ilusi Negara Islam; Ekspansi Gerakan Islam Transnasional di Indonesia, (Jakarta: The Wahid Institute, 2009).

Zuhairini, Sejarah Pendidikan Islam, (Jakarta: Direktorat Jendral Pendidikan Kelembagaan Agama Islam, 1986).

\section{Artikel Media:}

BBC, "Gugat Perppu, Hizbut Tahrir Indonesia Akan Ajukan Uji Materi ke MK" dalam http://www.bbc.com/indonesia/indonesia-40577915 pada 12 Juli 2017.

CNN, "FPI akan Ajukan Uji Materi Perppu Pembubaran Ormas" dalam https://www.cnnindonesia.com/nasional/20170713144041-12227638/fpi-akan-ajukan-uji-materi-perppu-pembubaran-ormas / pada 13 juli 2017.

Hukum Online.Com, "UU Ormas Mulai Memakan Korban" dalam http://www.hukumonline.com/berita/baca/lt5321da472379e/uuormas-mulai-memakan-korban pada 13 Maret 2014.

Kompas, "Fadli Zon Terima Forum Ormas Islam, Minta DPR Tolak Perppu Ormas" dalm http://nasional.kompas.com/read/2017/07/18/ 16220331/ fadli-zon-terima-forum-ormas-islam-minta-dpr-tolakperppu-ormas pada 18 Juli 2017. 
Kompas, "Ini Tiga Pertimbangan Pemerintah Menerbitkan Perppu Ormas" dalam http://nasional.kompas.com/read/2017/07/12/12232051/ ini-tiga-pertimbangan-pemerintah-menerbitkan-perppu-ormas pada 12 Juli 2017.

Koran Tempo, "UU Ormas Dikabulkan MK, Muhammadiyah Puas" dalam https://m.tempo.co/read/news/2014/12/26/078631006/uuormas-dikabulkan-mk-muhammadiyah-puas pada 26 Desember 2014.

Lembaga Administrasi Negara Republik Indonesia, Modul Pelatihan Analis Kebijakan, (PDF), hlm. 16-17. DIakses dari http://www.ksiindonesia.org/files/1447125643\$1\$2XL90\$.pdf pada 21 Mei 2016 pukul 15.05 wib.

MahkamahKonstitusi, "Putusan Mahkamah Konstitusi", Diakses melalui: http://www.mahkamahkonstitusi.go.id/index.php?page=web.Putusa n\&id=1\&kat=1\&cari=82\%2FPUU-XI\%2F2013 pada 23 Desember 2014.

Muhammadiyah, "Pernyataan Sikap Pimpinan Pusat Muhammadiyah No. 264/PER/I.0/A/2017 Tentang Pro Kontra Perppu Nomor 2 tahun 2017 dan Masalah Keberadaan Negara Pancasila" dalam http://www.aisyiyah.or.id/files/1/file/Pernyataan-Perpu-no-22017_compressed.pdf pada 9 Agustus 2017.

NU.OR.ID, “Perppu Ormas Mencegah Kerusakan" dalam https:// www.nu.or.id/post/read/79690/perppu-ormas-untuk-mencegahkerusakan pada 20 Juli 2017.

Republika, "MUI: Perppu Tidak Hanya Menyasar Salah Satu Ormas Saja" dlm http://www.republika.co.id/berita/nasional/hukum/17/07/ 13/oszp3x382-mui-perppu-seharusnya-tak-sasar-salah-satu-ormas pada 13 Juli 2017.

Tempo.co, "Perppu Ormas: Reaksi dari MUI, PBNU, hingga Fadli Zon" dalam https://nasional.tempo.co/read/news/2017/07/13/078891054/pe rppu-ormas-reaksi-dari-mui-pbnu-hingga-fadli-zon pada 13 Juli 2017. 